\title{
Activation of bimetallic PtFe nanoparticles with zeolite-type cesium salts of vanadium-substituted polyoxometallates toward electroreduction of oxygen at low Pt loadings for fuel cells
}

\author{
Marco Renzi ${ }^{1} \cdot$ Francesco Nobili ${ }^{1}\left[\right.$ Krzysztof Miecznikowski $^{2}\left[\right.$ Aldona Kostuch $^{2} \odot \cdot$ Anna Wadas $^{2} \cdot$ \\ Iwona A. Rutkowska² (D) Pawel J. Kulesza²
}

Received: 30 October 2021 / Revised: 8 November 2021 / Accepted: 8 November 2021 / Published online: 17 November 2021

(c) The Author(s) 2021

\begin{abstract}
The catalytic activity of commercial carbon-supported $\mathrm{PtFe}(\mathrm{PtFe} / \mathrm{C})$ nanoparticles admixed with mesoporous polyoxometalate $\mathrm{Cs}_{3} \mathrm{H}_{3} \mathrm{PMo}_{9} \mathrm{~V}_{3} \mathrm{O}_{40}$, (POM3-3-9), has been evaluated towards oxygen reduction reaction (ORR) in acid medium. The polyoxometalate cesium salt co-catalyst/co-support has been prepared by titration using the aqueous solution of phosphovanadomolibdic acid. The synthesized material has been characterized by transmission electron microscopy (TEM) and X-ray diffraction (XRD). The results confirm formation of the polyoxometalate salt with the characteristic Keggin-type structure. The composite catalyst has been prepared by mixing the POM3-3-9 sample with the commercial PtFe/C by sonication. The diagnostic rotating ring-disk voltammetric studies are consistent with good performance of the system with low Pt loading during ORR. The fuel cell membrane electrode assembly (MEA) utilizing the PtFe/POM-based cathode has exhibited comparable or better performance (at relative humidity on the level of 100,62, and 17\%), in comparison to the commercial MEA with higher Pt loading at the cathode. Furthermore, based on the cell potential and power density polarization curves, noticeable improvements in the fuel cell behavior have been observed at the low relative humidity (17\%). Finally, the accelerated stress test, which uses the potential square wave between $0.4 \mathrm{~V}$ and $0.8 \mathrm{~V}$, has been performed to evaluate MEA stability for at least $100 \mathrm{~h}$. It has been demonstrated that, after initial losses, the proposed catalytic system seems to retain stable performance and good morphological rigidity.
\end{abstract}

Keywords Oxygen reduction $\cdot \mathrm{PtFe}$ bimetallic catalyst $\cdot$ Phosphovanadomolibdate co-catalyst $\cdot$ Rotating ring-disk voltammetry $\cdot$ Fuel cell membrane electrode assembly $\cdot$ Accelerated stress test

\section{Introduction}

Nowadays, under current circumstances, where the energy needs grow daily and the extensive use of fossil fuels leads to severe environmental issues, the matter of alternative

Francesco Nobili

francesco.nobili@unicam.it

Krzysztof Miecznikowski

kmiecz@chem.uw.edu.pl

$\triangle$ Pawel J. Kulesza

pkulesza@chem.uw.edu.pl

1 University of Camerino, Via S. Agostino, 1, 62032 Camerino, MC, Italy

2 Faculty of Chemistry, University of Warsaw, Pasteura 1, 02-093 Warsaw, Poland energy sources raises rapidly. Therefore, many investigations have focused on the development of fuel cells (FCs), which have several benefits such as high efficiency, silent operating modes, low pollution level, and high durability [1]. Among various types of FCs, the low-temperature proton exchange membrane fuel cells (PEMFC) are the most promising candidates for clean and efficient energy conversion in portable and stationary small devices, as well as electric vehicle applications [2-5]. The basic structure of a PEMFC consists of a perfluorosulfonate proton exchange membrane in contact with porous electrodes, anode and cathode, coated with a catalyst to let the electrochemical reactions occur on both sides [6]. At the current stage of the technology, the most effective catalysts for the hydrogen oxidation reaction (HOR) and the oxygen reduction reaction (ORR) are platinum-based materials [7, 8]. However, the widespread commercialization of PEMFC technology has been greatly 
hindered mainly due to the high cost and scarcity of Pt materials [9]. Moreover, it has to be emphasized that the Pt loading is usually about 5-10 times higher on the cathode than on the anode due to the much slower kinetics of ORR than the HOR. Another obstacle to the full commercialization of the PEMFCs constitutes their short lifetime, which is commonly caused by catalyst degradation at the cathode side through the development of positive potentials inducing carbon support corrosion. This phenomenon leads to the dissolution of Pt particles, followed by their re-deposition that increases the particle's size and reduces active electrochemical surface area [10-16]. In fact, automotive and stationary fuel cell applications are typically limited to about $1700 \mathrm{~h}$ and $10,000 \mathrm{~h}$ of operations, respectively, while at least $5000 \mathrm{~h}$ and $40,000 \mathrm{~h}$ of continuous operation are required $[17,18]$. Therefore, in recent years, most of the research efforts have been devoted to reducing the cathode Pt loadings, without loss of performance and durability [19-27]. The decrease of Pt loading under $0.2 \mathrm{mg} \mathrm{cm}^{-2}$ maintaining the membrane electrode assembly (MEA) performance of $1000 \mathrm{~mW} \mathrm{~cm}^{-2}$, together with low relative humidity $(\mathrm{RH})$ operation and the enhancement of MEA lifetime are some of the important targets aimed at by the US Department of Energy (DOE) for 2020. Among possible strategies of the cost-reducing and improving durability is designing a carbon co-support that could allow improving metal active phase dispersion and limiting aggregation upon working conditions [28-32].

Heteropolyacids (HPAs) and polyoxometalates (POMs) are inorganic compounds used since before 1900, which are unmatched not only in terms of molecular and electronic structural versatility but also in terms of reactivity and relevance to analytical chemistry, catalysis, biology, medicine, geochemistry, materials science, and topology [33-36]. Several recent papers have considered the potential use of these materials in fuel cells due to their ability to strongly adsorb metal catalyst inside the micro-meso pores and their high acidity, which can be exploited to improve both durability and performance. In particular, the high acidity enhances the ORR kinetics, while the Pt particle aggregation is limited thanks to voids that can host nanosize Pt particles during operation [37-41]. Additionally, in order to avoid loss of performance due to the solubility of the heteropolyacids, their modification by partially exchanging protons of the parent acid with large cations such as $\mathrm{Cs}^{+}, \mathrm{K}^{+}$, and $\mathrm{NH}_{4}{ }^{+}$is carried out to prepare the insoluble salts. The performed study showed the highest surface area of $\mathrm{Cs}_{x} \mathrm{H}_{(3+n)-x} \mathrm{PMo}_{12-n} \mathrm{~V}_{n} \mathrm{O}_{40}$ when the Cs:HPA ratio is in the range of 2.5 to 3.5 [42]. Dsoke et al. [26] also revealed an improved ORR catalytic activity of Pt nanoparticles embedded inside insoluble W-based polyoxometalate (POM) salt, which synthesized from a Keggin-type heteropolyacid. Furthermore, enhancement of catalytic performance of the mixtures of $\mathrm{Pt}$ and $\mathrm{Pt}$ alloys with such types of co-supports was demonstrated [37-39, 43-47]. Especially, the $\mathrm{Cs}_{2.5} \mathrm{H}_{0.5} \mathrm{PW}_{12} \mathrm{O}_{40}$ was reported as excellent mesoporous support for Pt nanoparticles in the preparation of PEM electrodes with low Pt content [26, 43, 48-50].

In this work, we describe the synthesis of $\mathrm{Cs}_{3} \mathrm{H}_{3} \mathrm{PMo}_{9} \mathrm{~V}_{3} \mathrm{O}_{40}$ as co-catalytic material for fuel cell applications. The catalytic activity of commercial carbonsupported PtFe nanoparticles mixed with the obtained mesoporous polyoxometalate salt towards oxygen reduction reaction was evaluated. Preliminary electrochemical characterization was performed using different Pt loading, to estimate the influence of low Pt content on the ORR kinetics. Then, fuel cell tests were carried out with low cathode $\mathrm{Pt}$ loading and different relative humidity $(\mathrm{RH})$ values to assess the impact of the use of the proposed catalyst system toward performances in an operating fuel cell. Finally, the durability and stability of prepared materials were gauged by performing an accelerated stress test (AST).

\section{Experimental}

\section{POM synthesis}

In a typical synthesis of the $\mathrm{Cs}_{3} \mathrm{H}_{3} \mathrm{PMo}_{9} \mathrm{~V}_{3} \mathrm{O}_{40}$ insoluble salt [51], an aqueous solution of cesium carbonate $\left(\mathrm{Cs}_{2} \mathrm{CO}_{3}\right.$, Sigma-Aldrich, $\geq 99.00 \%$ ) was added drop-wise to phosphovanadomolibdic acid $\left(\mathrm{H}_{6} \mathrm{PMo}_{9} \mathrm{~V}_{3} \mathrm{O}_{40} \bullet 8 \mathrm{H}_{2} \mathrm{O}\right.$, hereafter labeled as PVM3-9, Nippon Inorganic Colour \& Chemical CO., LTD.) solution under vigorous stirring in a water bath at $50{ }^{\circ} \mathrm{C}$, which was continued for another $1 \mathrm{~h}$. Subsequently, the stirring of the fine suspension was kept overnight at room temperature. Next, the mixture was filtered under a vacuum filter system using a hydrophilic filter. The resulting products were dried overnight at $50{ }^{\circ} \mathrm{C}$. Hereafter, the obtained salt will be labeled as POM3-3-9.

\section{Physicochemical characterization}

Transmission electron microscopy (TEM) images were obtained with JEOL Model JSM-5400 equipped with a Shimadzu 800HS EDX detector. X-ray diffraction (XRD) spectra were recorded using an automated PHILIPS diffractometer equipped with a CuK $\alpha$ source $(\lambda=1.541 \AA)$.

\section{Electrode preparation and RRDE measurements}

For electrochemical measurements, the ink (PtFe/POM33-9) was prepared by mixing equivalent amount of the synthesized salt POM3-3-9 and commercial $20 \mathrm{wt} \% \mathrm{PtFe}$ on Vulcan XC-72 (Pt-Fe 1:1 atomic ratio, Premetek), and $985 \mu \mathrm{l}$ of isopropanol. The slurry was sonicated for $30 \mathrm{~min}$ to form a homogenous suspension. Immediately afterward, $15 \mu \mathrm{l}$ of 
5 wt $\%$ Nafion ${ }^{\circledR}$ solution (Ion-Power, Inc.) was added and the ink was put under vigorous stirring for further $30 \mathrm{~min}$. The POM3-3-9:PtFe:Nafion ratio was equal to 1:1:1. Commercial catalysts $20 \mathrm{wt} \%$ Pt on Vulcan XC-72 (Pt/C) and $20 \mathrm{wt} \%$ $\mathrm{PtFe}$ on Vulcan $\mathrm{XC}-72$ (PtFe/C) were used as references, and their inks were prepared according to the procedure described above but without POM addition. An appropriate amount of the catalysts ink was dropped onto the surface of a glassy carbon disc electrode through a Hamilton 701n syringe with the resultant $\mathrm{Pt}$ loadings on the electrode of 15 or $7.5 \mu \mathrm{g} \mathrm{cm}^{-2}$. The modified electrode surface was left to dry for $30 \mathrm{~min}$ in the air. The film thickness was typically in the order of $0.1 \mu \mathrm{m}$.

The rotating ring disk electrode (RRDE) method was applied to study the catalytic activity of the obtained materials towards the ORR. Electrochemical tests were conducted in a conventional three-electrode cell (Pine AKCELL3, USA), using a CH Instruments 750A (Austin, TX) bipotentiostat. The solution of $0.1 \mathrm{M} \mathrm{HClO}_{4}$ (Sigma-Aldrich, redistilled, $99.999 \%$ metal basis) was used as an electrolyte to avoid strongly adsorbing sulfate/bisulfates on Pt surface [52]. Prior to the electrochemical measurements, the electrolyte was deaerated (utilizing nitrogen) or saturated with oxygen for at least $30 \mathrm{~min}$ before each experiment and then during the tests. $\mathrm{A} \mathrm{K}_{2} \mathrm{SO}_{4}$-saturated $\mathrm{Hg} / \mathrm{Hg}_{2} \mathrm{SO}_{4}$ (MSE) electrode and a Pt wire were used as reference and counter electrodes, respectively. A glassy carbon disk, concentrically surrounded by a platinum ring (GCE-Pt, surface area $\mathrm{GCE}=0.2475 \mathrm{~cm}^{2}$, collection efficiency $(\mathrm{N}): 37 \%$ ), was used as the working electrode. In order to obtain an electrochemically clean and stable catalyst surface, a modified working electrode was activated by performing several full voltammetric potential cycles at $50 \mathrm{mV} \mathrm{s}^{-1}$ in an $\mathrm{N}_{2}$-saturated electrolyte until stable results were obtained. The RRDE experiments were carried out at a scan rate of $5 \mathrm{mV} \mathrm{s}^{-1}$ on the disk electrode, while a constant potential of $1.2 \mathrm{~V}$ vs. RHE (reversible hydrogen electrode) was applied to the ring electrode, with several rotating speeds ranging between 400 and $2500 \mathrm{rpm}$. The applied potentials were converted to the RHE scale. The recorded currents were normalized to the geometric area of the electrode and, additionally, corrected by subtracting the background currents measured in the $\mathrm{N}_{2}$ atmosphere.

\section{MEA preparation and fuel cell tests}

The PtFe/POM3-3-9 catalyst performance as ORR cathodic catalyst was evaluated in a $5 \mathrm{~cm}^{2}$ PEMFC. A Nafion 112 membrane of $60 \mu \mathrm{m}$ thickness (Ion-Power, Inc.) was used as the electrolyte, after pre-treating with $\mathrm{H}_{2} \mathrm{O}_{2}$ and $\mathrm{H}_{2} \mathrm{SO}_{4}$ to remove organic and inorganic impurities [53, 54]. The ink was prepared by following the same procedure reported in the "Electrode preparation and RRDE measurements" section but with a mass ratio PtFe/C:POM3-3-9:pure Nafion of 2:1:1. The electrodes were prepared by brushing the catalyst ink onto a gas diffusion layer (GDL, BASF), as uniformly as possible, to obtain a homogenous thickness throughout the entire surface. A commercial $20 \mathrm{wt} \% \mathrm{Pt} / \mathrm{C}$ (E-TEK) was used as an anodic catalyst. The Pt loading on the cathode was $0.2 \mathrm{mg} \mathrm{cm}^{-2}$, while on the anode was $0.5 \mathrm{mg} \mathrm{cm}^{-2}$, which allowed to avoid any possible limitations during the HOR. The reference MEA with both commercial anode and cathode (named MEA Comm.), with Pt loading of $0.5 \mathrm{mg} \mathrm{cm}^{-2}$, was also characterized. The MEA was obtained by hot pressing at $120^{\circ} \mathrm{C}$ and 50 bar for $3 \mathrm{~min}$. All the chemicals were used as obtained without further purification. Solutions were prepared using Millipore Milli$\mathrm{Q}$ water of resistivity $\approx 17 \mathrm{M} \Omega \mathrm{cm}$.

For the PEMFC test, the MEA was mounted into a $5-\mathrm{cm}^{2}$ triple-serpentine cell (model 05-02 from Electrochem. Inc). A fuel cell test bench (Scribner Associated 890CL) was used for the evaluation. The anodic and cathodic compartments were fed with pure $\mathrm{H}_{2}\left(100 \mathrm{ml} \mathrm{min}^{-1}\right)$ and pure $\mathrm{O}_{2}$ $\left(200 \mathrm{ml} \mathrm{min}^{-1}\right)$, respectively. The gas pressure was maintained constant at 2 bar. The fuel cell performances were characterized by holding the cell temperature at $70{ }^{\circ} \mathrm{C}$, while the temperatures of the gas humidifiers were changed in order to obtain different inlet gas humidity values, which result in different final RHs. The temperatures of cell and feed gases are hereafter specified as TA/TM/TC, where TA and TC are anode and cathode feed gas temperatures, respectively, while TM is cell temperature $\left({ }^{\circ} \mathrm{C}\right)$. Before starting tests, the activation cell process was performed feeding fully humidified ( $100 \% \mathrm{RH})$ oxygen and hydrogen at cathode and anode, respectively, until stable polarization curves were obtained. All the potentials are reported versus the reversible hydrogen electrode (RHE).

\section{Results and discussion}

\section{Structural and morphological characterization}

The prepared catalytic materials were characterized for their phase structure and crystallinity by X-ray powder diffraction (XRD). The typical XRD patterns of PtFe/C, POM3-3-9, and POM3-3-9-modified PtFe/C are displayed in Fig. 1. The results revealed the presence of the crystalline POM3-3-9 with a characteristic cubic $(P n 3 m)$ Keggin-type structure commonly associated with the pure alkaline heteropolysalts [55]. Due to the introduction of larger $\mathrm{Cs}^{+}$cations into the heteropolyacid lattice, which greatly influences the tertiary structure, the shifting in the diffraction peaks towards the lower $2 \theta$ angels is observed in comparison to the pure PVM3-9 acid [56]. The XRD patterns of modified and unmodified $\mathrm{PtFe} / \mathrm{C}$ samples show the diffraction peaks at $2 \theta$ 


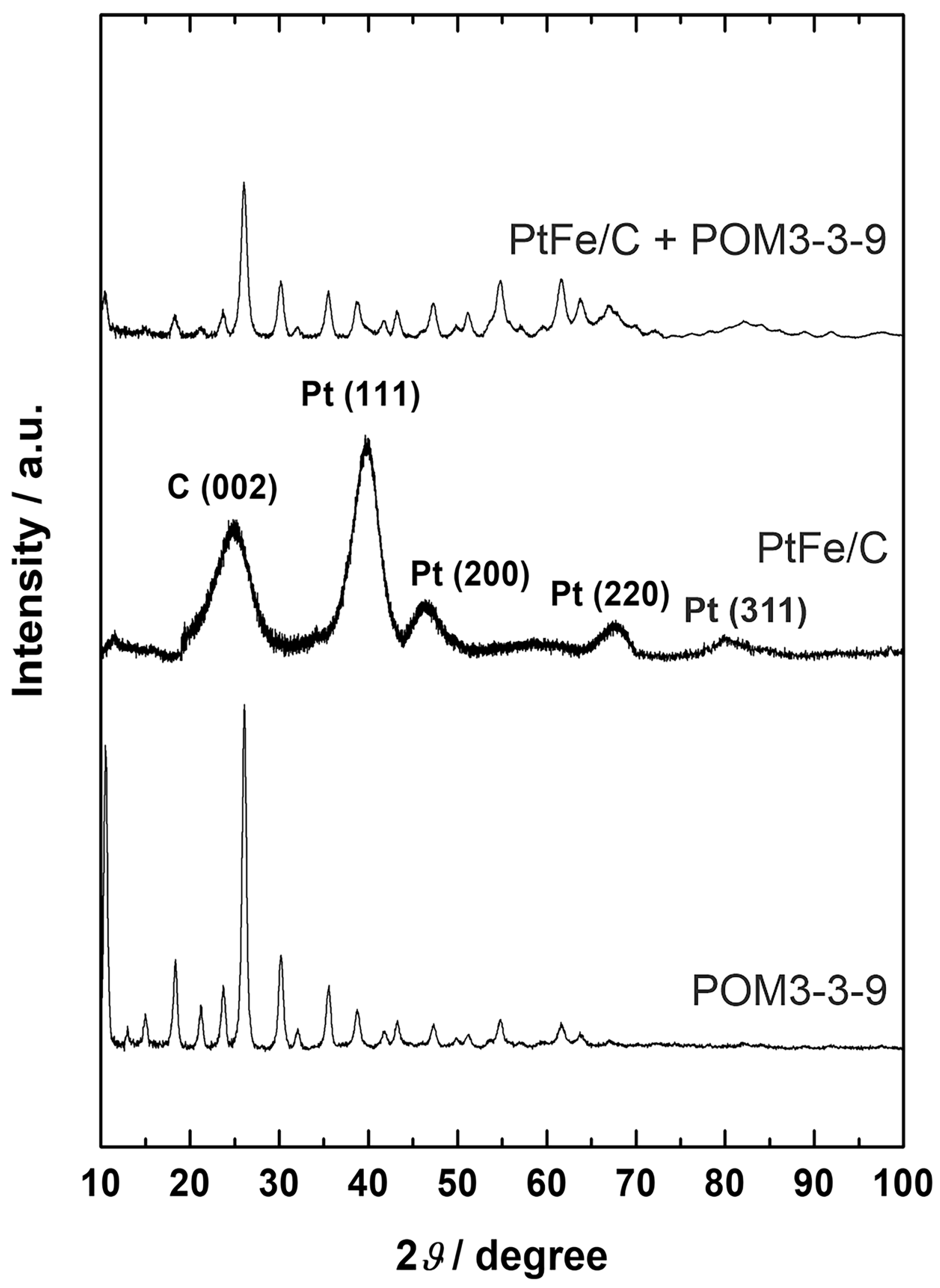

Fig. 1 X-ray diffraction patterns of the PtFe/C, POM3-3-9, and POM3-3-9-modifed PtFe/C samples 


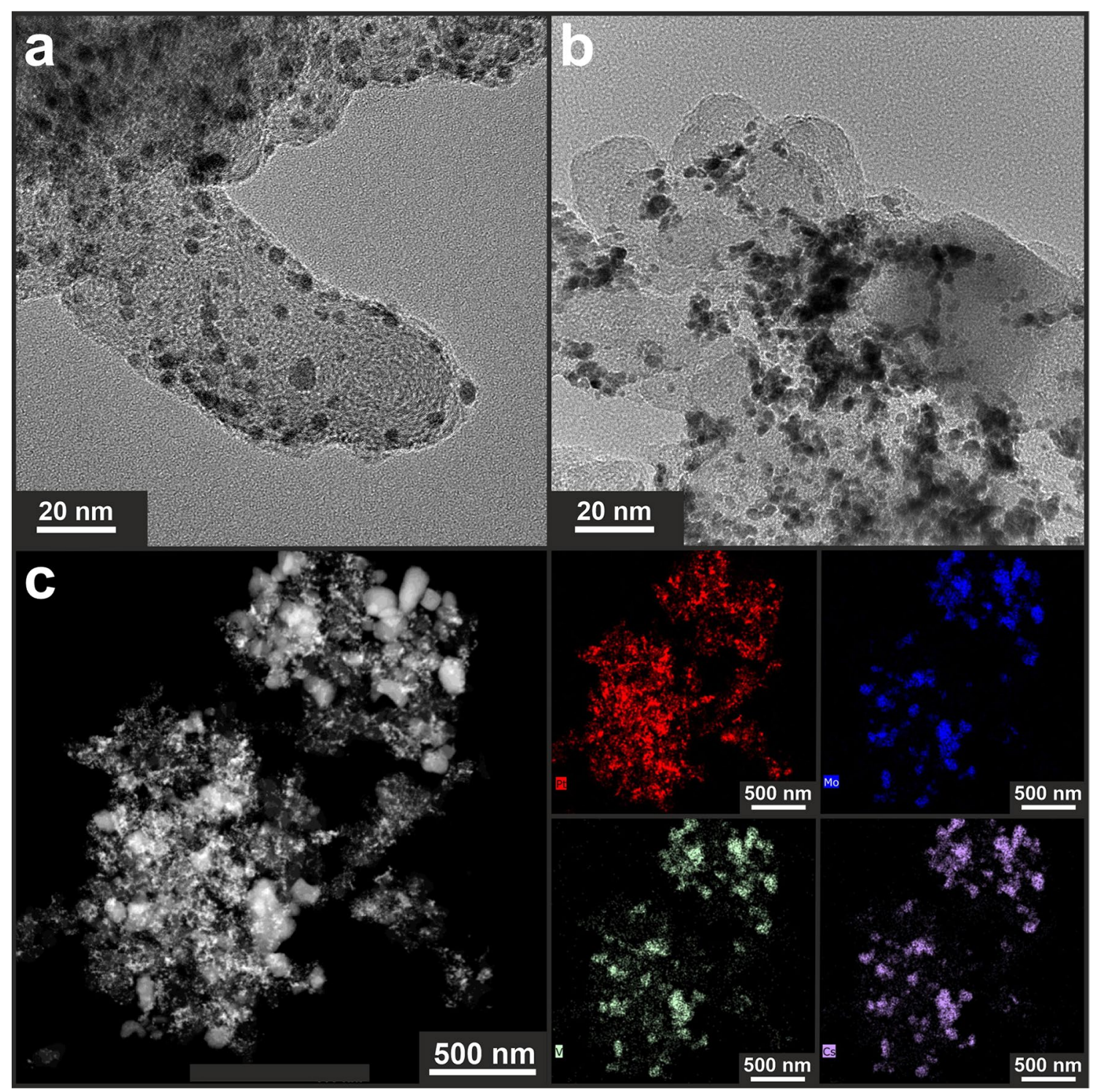

Fig. 2 TEM images of the a PtFe/C and b POM3-3-9-modified PtFe/C samples. Additionally, EDX maps of the POM3-3-9-modified PtFe/C catalyst are presented (c)

of $39.3^{\circ}, 45.3^{\circ}, 66.7^{\circ}$, and $79.9^{\circ}$ assigned to the Pt planes (111), (200), (220), and (311), respectively. The positions of these peaks are shifted towards lower $2 \theta$ angels compared to pristine Pt (JCPDS\# 04-0802), which is related to the effect of alloying. Furthermore, due to the presence of the carbon support, a wide peak at $\sim 25^{\circ}$ that corresponds to the graphite plane (002) can also be distinguished [57, 58].

The morphology of the catalytic materials was examined by transmission electron microscopy, and the obtained results are presented in Fig. 2a, b. The TEM images show a uniform distribution of spherical or quasi-spherical PtFe nanoparticles on unmodified and POM-modified carbon support. Moreover, microscopic analysis confirmed the nanometric size of the alloy nanocrystals. In the case of the unmodified samples, the average size of the PtFe particles in the range of 6-12 nm was observed, while for the POM33-9, modified catalysts were varied between 8 and $14 \mathrm{~nm}$. Additionally, the EDX maps (Fig. 2c) were obtained to get more information about the distribution of $\mathrm{PtFe} / \mathrm{C}$ nanoparticles in the presence and absence of POM3-3-9.

\section{Electrochemical characterization}

The cyclic voltammetric curves of the PtFe/POM3-3-9 and $\mathrm{PtFe} / \mathrm{C}$ samples with different amounts of Pt loadings on the electrode surface, equal to $15 \mu \mathrm{g} \mathrm{cm}^{-2}$ and $7.5 \mu \mathrm{g} \mathrm{cm}^{-2}$, are shown in Fig. 3a, b, respectively. The well-known voltammetric pattern of the carbon supported $\mathrm{Pt}(\mathrm{Pt} / \mathrm{C}$, loading 


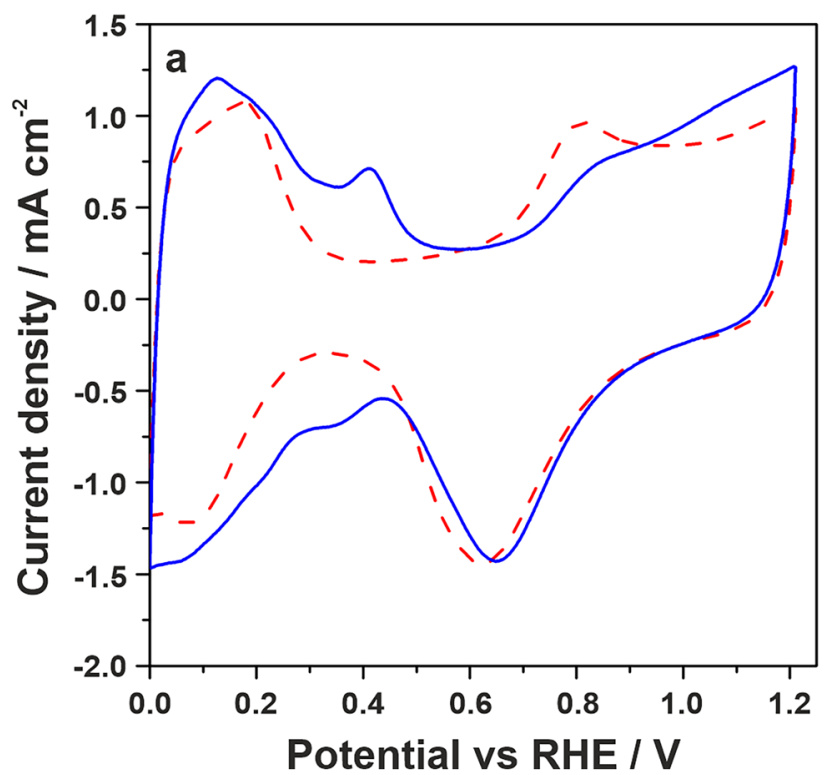

Fig. 3 Cyclic voltammograms of POM3-3-9-modified PtFe/C catalyst (blue solid line) compared with POM-free $20 \% \mathrm{PtFe} / \mathrm{C}$ reference sample (red dash line), with different content of Pt loadings:

$15 \mu \mathrm{g} \mathrm{cm}^{-2}$ ) with the characteristic hydrogen adsorption/ desorption peaks and the broader peak reflecting formation of Pt-oxo species is provided in Supplementary Information (Fig. S1). In all cases, within the potential range from 0 to $0.3 \mathrm{~V}$, typical phenomena, such as hydrogen adsorption/desorption (below $\sim 0.3 \mathrm{~V}$ ) together with the $\mathrm{Pt} / \mathrm{PtO}$ redox couple (in the potential region above $\sim 0.6 \mathrm{~V}$ ), can be observed. Furthermore, the well-defined redox peaks for the PtFe/POM3-3-9 are noticed in the potential range, $0.3-0.45 \mathrm{~V}$. Based on previously reported voltammograms for Pt-free POMs [59], the observed redox couple should be assigned to oxidation/reduction reactions of the molybdate component of POM3-3-9. However, due to the overlapping with hydrogen adsorption/desorption peaks and formation Pt-oxo process, clear distinction and interpretation of all POM3-3-9 redox transitions are not possible. For the same reasons, determination of the electrochemical surface area (ECSA) and the roughness factor has not been done here.

In order to examine the ORR activity, the voltammetric measurements of the investigated catalysts using the RRDE method were performed in an $\mathrm{O}_{2}$-saturated electrolyte solution. The ORR curves for the PtFe/POM3-3-9 sample compared to benchmark 20\% $\mathrm{Pt} / \mathrm{C}$ and $20 \% \mathrm{PtFe} / \mathrm{C}$ catalysts recorded at $1600 \mathrm{rpm}$ are demonstrated in Fig. 4. The recorded potentiodynamic curves for all studied catalysts are characterized by similar profiles over the entire examined potential window, with the limiting current density of $\sim 5.75 \mathrm{~mA} \mathrm{~cm}^{-2}$. As it can be seen in Fig. 4a, the half-wave potentials $\left(E_{1 / 2}\right)$ for catalysts with $\mathrm{PtFe}$ alloys are positively

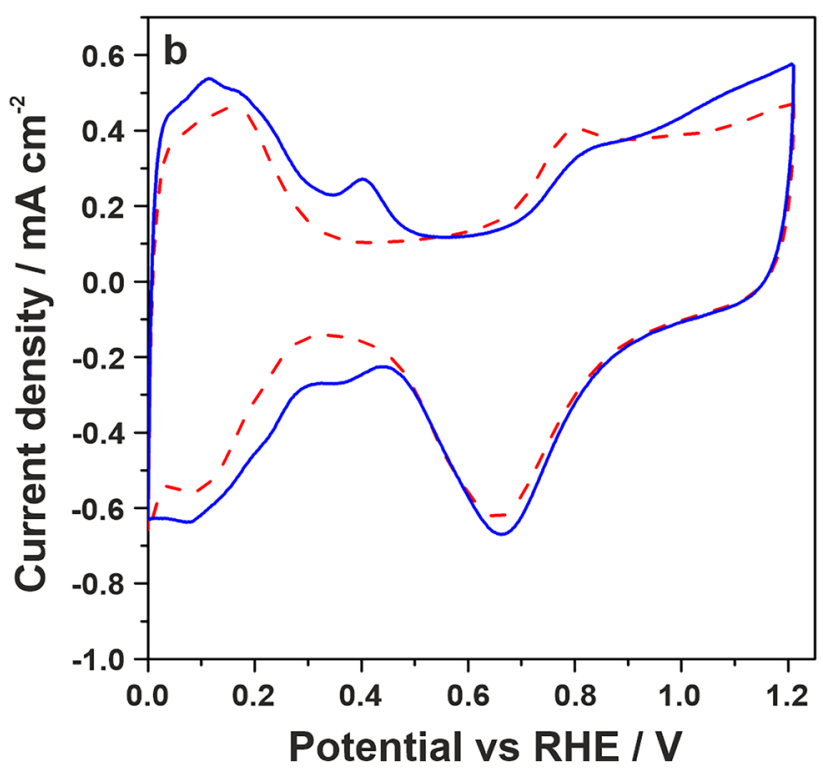

a $15 \mu \mathrm{g} \mathrm{cm}{ }^{-2}$ and $\mathbf{b} 7.5 \mu \mathrm{g} \mathrm{cm}^{-2}$. Electrolyte: deoxygenated $\mathrm{HClO}_{4}$ $(0.1 \mathrm{M})$. Scan rate: $50 \mathrm{mV} \mathrm{s}^{-1}$

shifted, when compared to the Pt/C, ca. $71 \mathrm{mV}$ for the $\mathrm{PtFe} / \mathrm{C}$ and $54 \mathrm{mV}$ for the PtFe/POM3-3-9, despite of the same Pt loadings $\left(15 \mu \mathrm{g} \mathrm{cm}^{-2}\right)$. The higher potential values indicate lower activation energy due to more favorable kinetics of the ORR process. The slightly lower $E_{1 / 2}$ in the case of POM-modified catalyst can be related to the higher thickness of the layer after modification, with respect to the reference samples. The enhancement catalytic activity in comparison to $\mathrm{Pt} / \mathrm{C}$ was also confirmed in the case of measurements with lower Pt content $\left(7.5 \mu \mathrm{g} \mathrm{cm}^{-2}\right)$, with a half-wave potential shift towards a positive value of $19 \mathrm{mV}$ for $\mathrm{PtFe} / \mathrm{C}$ and $29 \mathrm{mV}$ for PtFe/POM3-3-9 (Fig. 4c).

To delineate the pathways of the oxygen reduction reaction on the obtained catalysts, from the recorded RRDE profiles, the percentage of the produced hydrogen peroxide species with respect to the total ORR products was calculated according to Eq. (1) [60]:

$\% \mathrm{H}_{2} \mathrm{O}_{2}=\frac{200 \frac{I_{r}}{N}}{I_{d}+\frac{I_{r}}{N}}$

where $I_{\mathrm{d}}$ is the current measured at the GC disk, $I_{\mathrm{r}}$ is the current measured at the $\mathrm{Pt}$ ring, and $N$ is the collection efficiency.

Figure $4 b$, d illustrate the percent content of $\mathrm{H}_{2} \mathrm{O}_{2}$ oxidized at the ring electrode as a function of the potential applied to the disk electrode. The amount of produced hydrogen peroxide species at $0.6 \mathrm{~V}$ (the potential relevant to fuel cell cathodes) is around 3\% for the commercial $20 \%$ 

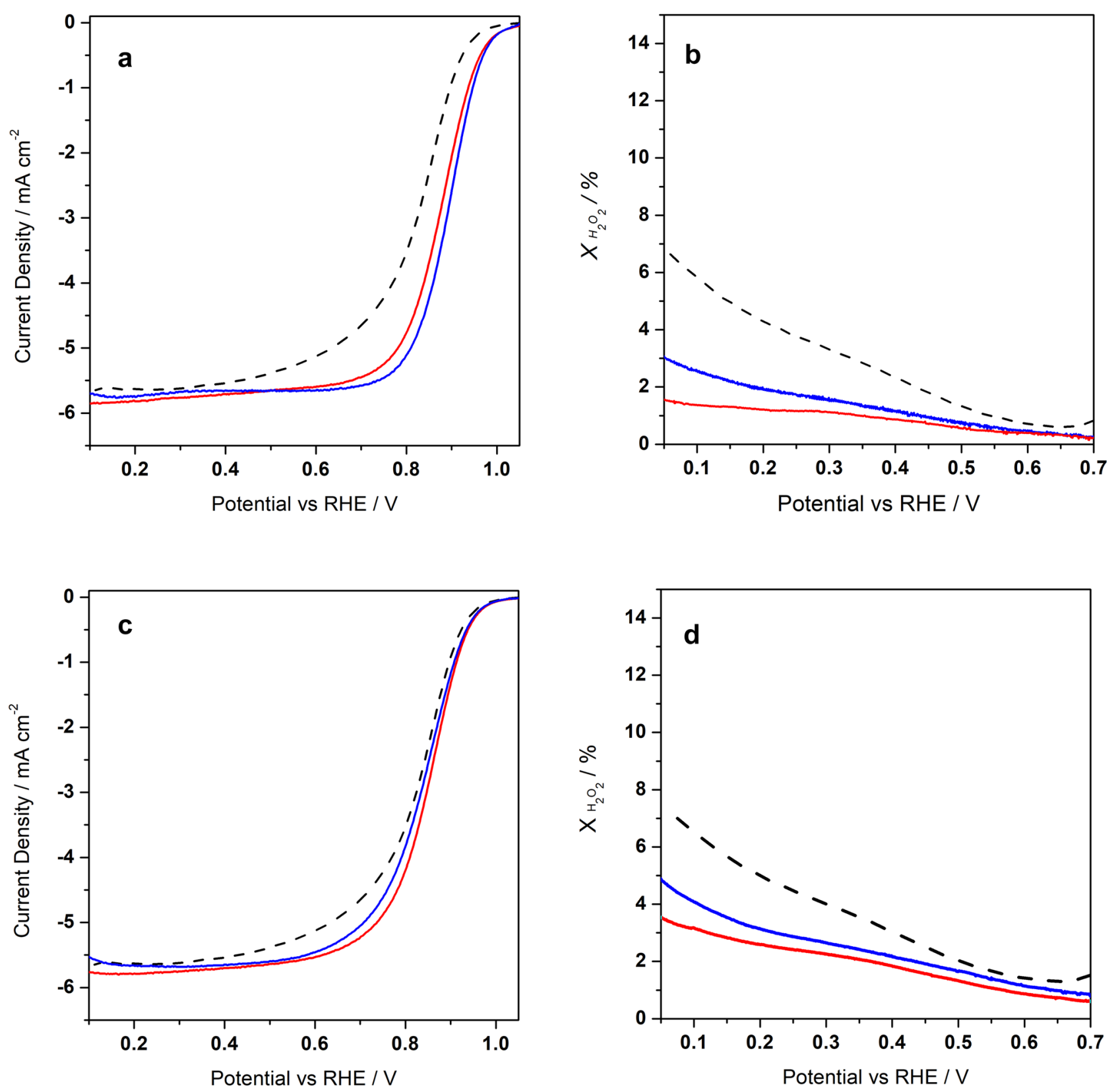

Fig. 4 a, c The ORR curves for the POM3-3-9-modified PtFe/C sample (red line) compared to benchmark $20 \% \mathrm{Pt} / \mathrm{C}$ (black dash line) and $20 \% \mathrm{PtFe} / \mathrm{C}$ (blue line) catalysts recorded in $\mathrm{O}_{2}$-saturated $0.1 \mathrm{M}$ $\mathrm{HClO}_{4}$ solution at $1600 \mathrm{rpm}$ and the scan rate of $5 \mathrm{mV} \mathrm{s}^{-1}$, with cor-

responding $\mathbf{b}$, d percentage of $\mathrm{H}_{2} \mathrm{O}_{2}$ calculated from the RRDE measurements with $E_{\text {ring }}=1.2 \mathrm{~V}$. The tests were performed with different content of Pt loadings: a, b $15 \mu \mathrm{g} \mathrm{cm} \mathrm{cm}^{-2}$ and $\mathbf{c}, \mathbf{d} 15 \mu \mathrm{g}_{\mathrm{Pt}} \mathrm{cm}^{-2}$ for $\mathrm{Pt} / \mathrm{C}$, and $7.5 \mu \mathrm{g}_{\mathrm{Pt}} \mathrm{cm}^{-2}$ for PtFe/C and POM3-3-9-modified PtFe/C

$\mathrm{Pt} / \mathrm{C}$ layer. Independently from the metal loadings, a value of formed $\mathrm{H}_{2} \mathrm{O}_{2}$ less than $1 \%$ for unmodified and POMmodified $\mathrm{PtFe}$ samples was observed, which implies that the reduction of oxygen proceeds along a favorable fourelectron pathway. Furthermore, in all cases, a significant increase in the ring current was detected when the disk potential approached the $\mathrm{H}$-underpotential deposition region $(0.05-0.3 \mathrm{~V})$. This phenomenon is generally related to hydrogen adsorption on $\mathrm{Pt}$ surface defects which leads to

decreases in the number of neighboring Pt atoms, thereby reducing the ORR selectivity $[60,61]$.

The data were also analyzed by considering the KouteckyLevich (K-L) model, assuming that only transport of oxygen in solution or the chemical (catalytic) reaction was the ratedetermining steps. For this purpose, the dependency of the reciprocal values of the experimental current density on the square root of the rotation rate can be demonstrated on the $\mathrm{K}-\mathrm{L}$ plots and expressed by the following equations [62-64]: 
$\frac{1}{j}=\frac{1}{j_{\mathrm{k}}}+\frac{1}{j_{\mathrm{L}}}=\frac{1}{n \mathrm{~F} k_{\mathrm{het}} C_{\mathrm{O}_{2}}^{o}}+\frac{1}{j_{L}}$

where $j$ is the measured current density, $j_{\mathrm{k}}$ is the kinetic current density, $j_{\mathrm{L}}$ is the diffusion limited current density (given by the Levich equation), $n$ is the number of transferred electrons, $F$ is the Faraday constant $\left(96.485 \mathrm{C} \mathrm{mol}^{-1}\right), k_{\text {het }}$ is the electron-transfer heterogeneous rate constant $\left(\mathrm{cm} \mathrm{s}^{-1}\right), C_{\mathrm{O}_{2}}^{o}$ is the bulk concentration of oxygen (in $0.1 \mathrm{M} \mathrm{HClO}_{4}, \mathrm{C}_{\mathrm{O}_{2}}^{o}=$ $\left.1.38 \times 10^{-6} \mathrm{~mol} \mathrm{~cm}^{-3}[59]\right)$.

The K-L plots (for simplicity not shown here) that were prepared for the investigated samples at $0.75 \mathrm{~V}$ are characterized by non-zero intercepts clearly indicating kinetic limitation associated with the catalytic film. Based on the intercepts of the reciprocal plots, the kinetic parameter, $k_{\text {het }}$, which reflects intrinsic rates of heterogeneous charge transfer was estimated. The calculated values (Table 1) are as follows: $0.22 \mathrm{~cm} \mathrm{~s}^{-1}$ for $\mathrm{Pt} / \mathrm{C}$, and they lie in the range from 0.1 to $0.3 \mathrm{~cm} \mathrm{~s}^{-1}$ for the other systems, reaching the highest value for PtFe/POM3-3-9 $\left(15 \mu \mathrm{gPt} \mathrm{cm}^{-2}\right)$.

Also, onset potentials for ORR under RRDE conditions are summarized in Table 1. To make comparison accurate, we consider here the onset potentials as equivalent to the potentials at which the measured currents reach the 5\% level of the respective convectional-diffusional limiting (maximum) currents. Such parameters were postulated to have the kinetic meaning because they are related to the purely kinetic performance of the ORR electrocatalytic systems [65]. On the whole, it can be concluded that the POM-salt admixied or supported PtFe systems seem to be characterized by the most positive potential values at which ORR becomes operative.

Additional kinetic analysis for all the investigated catalysts was addressed using Tafel plots, which were obtained at the low overpotential region (Fig. 5) and prepared after correction for mass transport limitation [62]:

$j_{k}=\frac{j_{L} \times j}{j_{L}-j}$

Table 1 Comparison among the calculated values of $k_{\text {het }}$ and $E_{\text {onset }}$ for investigated samples

\begin{tabular}{|c|c|c|}
\hline Sample & $\begin{array}{l}k_{\text {het }} \text { at } 0.75 \mathrm{~V} / \\
\mathrm{cm}^{-1} \mathrm{~s}^{-1}\end{array}$ & $E_{\text {onset }} / \mathbf{V}$ \\
\hline $\mathrm{Pt} / \mathrm{C}\left(15 \mu \mathrm{gPt} \mathrm{cm}^{-2}\right)$ & 0.22 & 0.930 \\
\hline $\mathrm{PtFe} / \mathrm{C}\left(15 \mu \mathrm{gPt} \mathrm{cm}^{-2}\right)$ & 0.20 & 0.975 \\
\hline PtFe/POM3-3-9 $\left(15 \mu \mathrm{gPt} \mathrm{cm}{ }^{-2}\right)$ & 0.30 & 0.970 \\
\hline $\mathrm{PtFe} / \mathrm{C}\left(7.5 \mu \mathrm{gPt} \mathrm{cm}{ }^{-2}\right)$ & 0.10 & 0.935 \\
\hline PtFe/POM3-3-9 $\left(7.5 \mu \mathrm{gPt} \mathrm{cm}{ }^{-2}\right)$ & 0.18 & 0.950 \\
\hline
\end{tabular}

where $j_{\mathrm{k}}$ is the mass transport corrected kinetic current density, $j_{\mathrm{L}}$ is the diffusion limited current density, and $j$ is the measured current density.

The relevant values of mass activities, $0.343 \mathrm{~mA}$ $\mu \mathrm{g}_{\mathrm{Pt}}{ }^{-1}$ for $\mathrm{PtFe} / \mathrm{C}$ and $0.356 \mathrm{~mA} \mu \mathrm{g}_{\mathrm{Pt}}{ }^{-1}$ for POM33-9-modified $\mathrm{PtFe} / \mathrm{C}$, have been determined from Tafel plots $E$ vs $\log j_{k}$ measured at $0.9 \mathrm{~V}$ where the influence of mass transport is negligible [59]. The results are consistent with reasonably high catalytic activity of the Pt-based catalysts.

For the benchmark platinum catalyst, the Tafel slope changes from $\sim 60 \mathrm{mV} \mathrm{dec}{ }^{-1}$ at lower overpotentials to $\sim 120 \mathrm{mV} \mathrm{dec}^{-1}$ at higher overpotentials indicating that the only rate-determining step (RDS) over the entire potential range is the initial electron transfer [66]. Based on the microkinetic modeling, this phenomenon was explained in terms of the influence of oxygen-containing reaction intermediates on the rate at low overpotentials through partially surface site-blocking, even if their removal takes place by fast quasi-equilibrated steps. The coupling between the removing processes of intermediates from the catalyst surface and the RDS leads to a changeable Tafel slope, which is dependant on the coverage and potential [66].

In the cases of unmodified and POM-modified $\mathrm{PtFe} / \mathrm{C}$ catalysts, shifting of $\log \left(j_{\mathrm{L}} \times j\right) /\left(j_{\mathrm{L}}-j\right)$ toward positive values has been observed, which implies better kinetics when compared to the reference $\mathrm{Pt} / \mathrm{C}$ layer. In particular, the layer of low Pt loading present higher performance with respect to $\mathrm{Pt} / \mathrm{C}$, probably due to the activation effect of the combination of both $\mathrm{Fe}$ and POM components. Some uncertainty may arise from the site-blocking by $\mathrm{OH}_{\text {ads }}$ intermediates and the related electronic effects [67]. It is reasonable to expect that, in the presence of POM and Fe sites, formation of $\mathrm{OH}_{\mathrm{ads}}$ intermediates is suppressed. This statement can be rationalized in terms of the catalytic activity of additives (particularly POM) toward decomposition of hydrogen peroxide intermediate or mutual activating interactions between $\mathrm{Pt}$ and co-catalytic additives. But the performance improvement is likely to be somewhat hindered by the catalytic site dilution effect due to the presence of additional materials on the electrode surface and higher resistance to charge (electron, ion) transfers. On the other hand, the most promising results have been observed during ORR at the low Pt loading system utilizing the PtFe/POM3-3-9 modified layer. While the catalyst's morphology is likely to be the crucial issue (further research is needed along this line), the co-catalytic effect originating from the combination of both POM and $\mathrm{Fe}$ additives can be postulated. The obtained results imply potential utility of the low Pt loading Pt-Fe/POM-type catalysts in fuel cell research. 


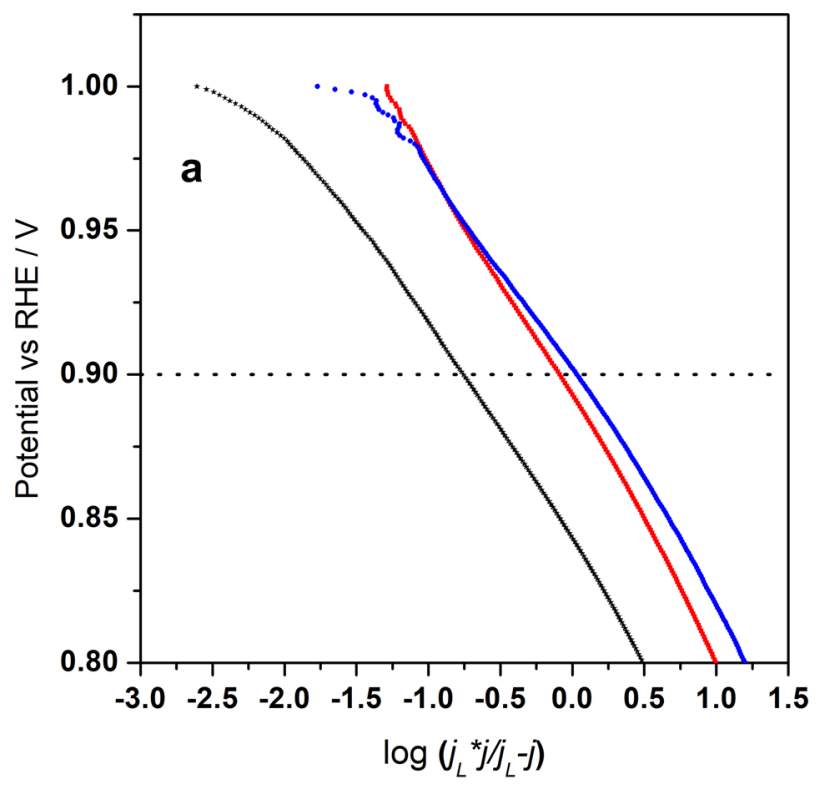

Fig. 5 Tafel plots based on the data reported in Fig. 4a, c for the POM3-3-9-modified PtFe/C sample (red points) compared to benchmark 20\% Pt/C (black points) and 20\% PtFe/C (blue points) catalysts.

\section{Application in fuel cell}

The polarization and power density curves of MEA PtFe/ POM3-3-9 at different relative hymidities (RHs), namely $100 \%, 62 \%$, and $17 \%$ RHs, are presented in Fig. 6, in comparison to the commercial membrane electrode assembly (MEA). These results were recorded after $3 \mathrm{~h}$ of the activation process when the open-circuit voltage (OCV) reached steady values close to $0.96 \mathrm{~V}$ [48]. In the case of application of $100 \%$ and $62 \% \mathrm{RH}$, the POM-modified MEA shows comparable performance in terms of the current density in the region of the activation loss $(0.65 \mathrm{~V})$ with respect to commercial reference MEA, despite reducing of Pt loading at the cathode. The modified MEA is characterized by the current density values, $228 \mathrm{~mA} \mathrm{~cm}^{-2}$ at $100 \% \mathrm{RH}$ and $167 \mathrm{~mA} \mathrm{~cm}^{-2}$ at $62 \% \mathrm{RH}$, which are lower than that of the reference MEA. But in the case of the lower relative humidity, $\mathrm{RH}=17 \%$, the MEA with $\mathrm{PtFe} /$ POM3-3-9 has exhibited the current density $79 \mathrm{~mA} \mathrm{~cm}^{-2}$ higher than that characteristic of commercial MEA. It is noteworthy that the $\mathrm{H}^{+}$excess in the cathode region faciltates the activation process and improves the ORR kinetics by maintaining hydration and counteracting the performance loss visible for the commercial MEA (MEA Comm) at higher RH values $[59,68]$. Moreover, at low RH conditions, any possible flooding is likely to be absent at the cathode and results in the performance enhancement. In addition, it is believed that the mesoporous POM can act as water reservoir to maintain good hydration of the Nafion membrane despite the low RH [69]. Also, in

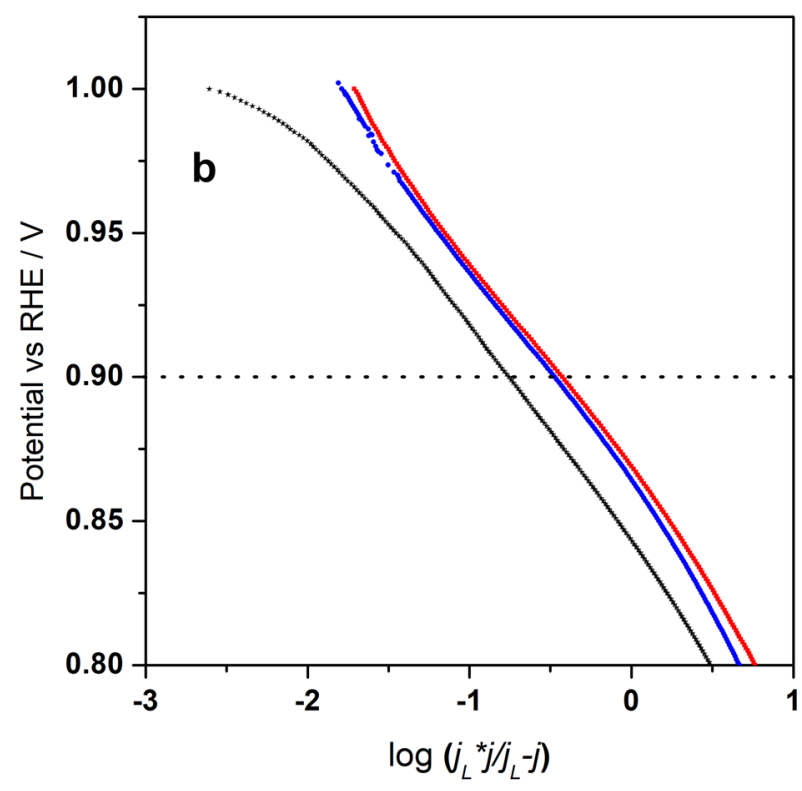

The content of Pt loadings on the electrode surface was a $15 \mu \mathrm{g}_{\mathrm{P}_{\mathrm{t}}}$ $\mathrm{cm}^{-2}$ for all sample, and $\mathbf{b} 15 \mu \mathrm{g}_{\mathrm{Pt}} \mathrm{cm}^{-2}$ for $\mathrm{Pt} / \mathrm{C}$, and $7.5 \mu \mathrm{g}_{\mathrm{Pt}} \mathrm{cm}^{-2}$ for $\mathrm{PtFe} / \mathrm{C}$ and $\mathrm{POM} 3-3-9-m o d i f i e d ~ \mathrm{PtFe} / \mathrm{C}$

the low polarization region (at $0.3 \mathrm{~V}$ ), the representative polarization and power curves characteristic of the MEA with PtFe/POM3-3-9 show higher current density values. Having in mind the low Pt cathode loading of the modified MEA, it is reasonable to expect some contribution of POM toward the gas transport properties. In the presence of the $\mathrm{Fe}$ additive, the Pt loading can be further lowered, in comparison to that described recently [68], thus maintaining the performance close to that characteristic of commercial MEA at high RHs, and yielding better performance at the low RH. The relevant data are summarized in Table 2.

In a case of the low cell humidity, the presence of POM and $\mathrm{Fe}$ tended to enhance the interfacial charge transfer, thus promoting the ORR and compensating for the low Pt content at the cathode. These results can be explained in terms of the high surface POM acidity which enhances proton availability and consequently ORR kinetics. Furthermore, the Fe component seems to promote - in the presence of POM33-9 - the four-electron oxygen reduction. Finally, the high mesoporosity and zeolitic nature of POM facilitates formation of the humidity reservoir capable of maintaining threeboundary contact between polymer electrolyte, electrode, and gaseous fuel.

Because the stability of Pt-based bimetallic alloy catalysts is far from meeting the requirement for practical long-term operations, the accelerated stress test (AST) based on the procedure used in the recent work [68] has been performed here (Fig. 7) to evaluate durability of the performance of the electrocatalyst as well as the persistence of its activity during long-term experiments 

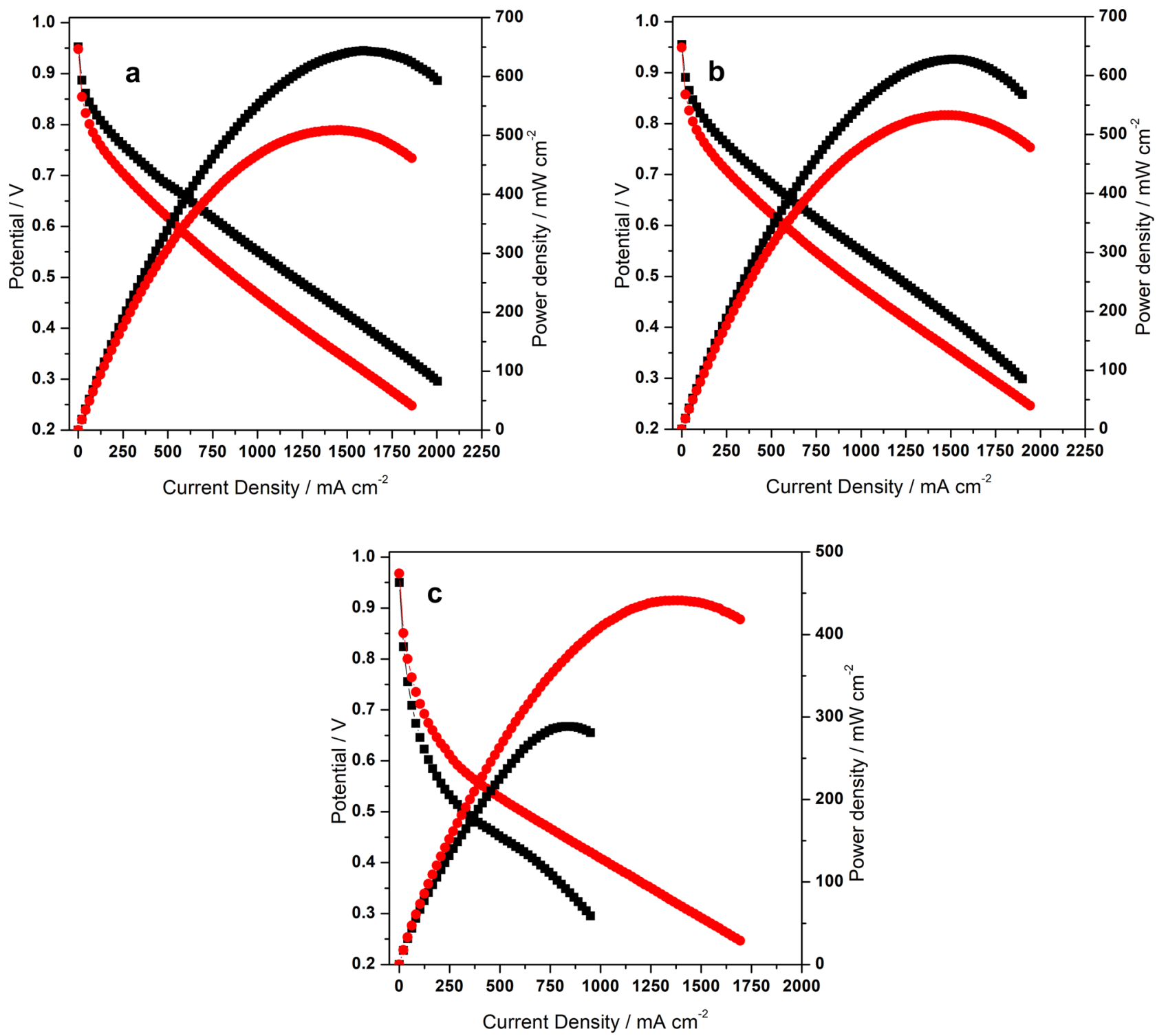

Fig. 6 Polarization and power density curves obtained using the POM3-3-9-modified $\mathrm{PtFe} / \mathrm{C}$ catalyst (red points) and a commercial $\mathrm{Pt} / \mathrm{C}$ catalyst (black points) at the cathode at different relative humid-

at conditions of the fuel cell operation. Under such circumstances, the particles of metal catalysts are subject to the continuous growth and dissolution, especially upon application of high electrode potentials. Indeed, serious problems related to the dissolution of $\mathrm{Fe}$, its growth, or loss were reported for bimetallic PtFe catalysts [70-72]. The parasite processes of dissolution and sintering are typically accelerated under repetitive potential cycling conditions. Our present results are, generally, consistent with good stability and persistence of performance after $96 \mathrm{~h}$ operation. The decrease in the current density has only been on the level $85 \mathrm{~mA} \mathrm{~cm}^{-2}$. It is reasonable to attribute the improvement in stability to the presence of ity: a $100 \% \mathrm{RH}\left(T=70 / 70 / 70{ }^{\circ} \mathrm{C}\right)$; b $62 \% \mathrm{RH}\left(T=60 / 70 / 60{ }^{\circ} \mathrm{C}\right)$; c $17 \% \mathrm{RH}\left(T=40 / 70 / 40{ }^{\circ} \mathrm{C}\right)$. Feed gases: $\mathrm{H}_{2} 100 \mathrm{ml} \mathrm{min}{ }^{-1}$, $\mathrm{O}_{2} 200 \mathrm{ml} \mathrm{min}^{-1}, \mathrm{P}=2$ bar

Table 2 Performance parameters for fuel cell tests in Fig. 6 for the POM3-3-9-modified PtFe/C catalyst and the commercial Pt/C catalyst

\begin{tabular}{llll}
\hline RH/\% & & MEA comm & $\begin{array}{l}\text { MEA PtFe/ } \\
\text { POM3-3-9 }\end{array}$ \\
\hline 100 & $\boldsymbol{E} / \mathbf{V}$ & Current density/mA cm & $\mathbf{- 2}$ \\
& 0.65 & 626 & 398 \\
62 & 0.3 & 1986 & 1662 \\
& 0.65 & 584 & 417 \\
17 & 0.3 & 1890 & 1722 \\
& 0.65 & 99.7 & 180 \\
& 0.3 & 941.8 & 1465 \\
\hline
\end{tabular}



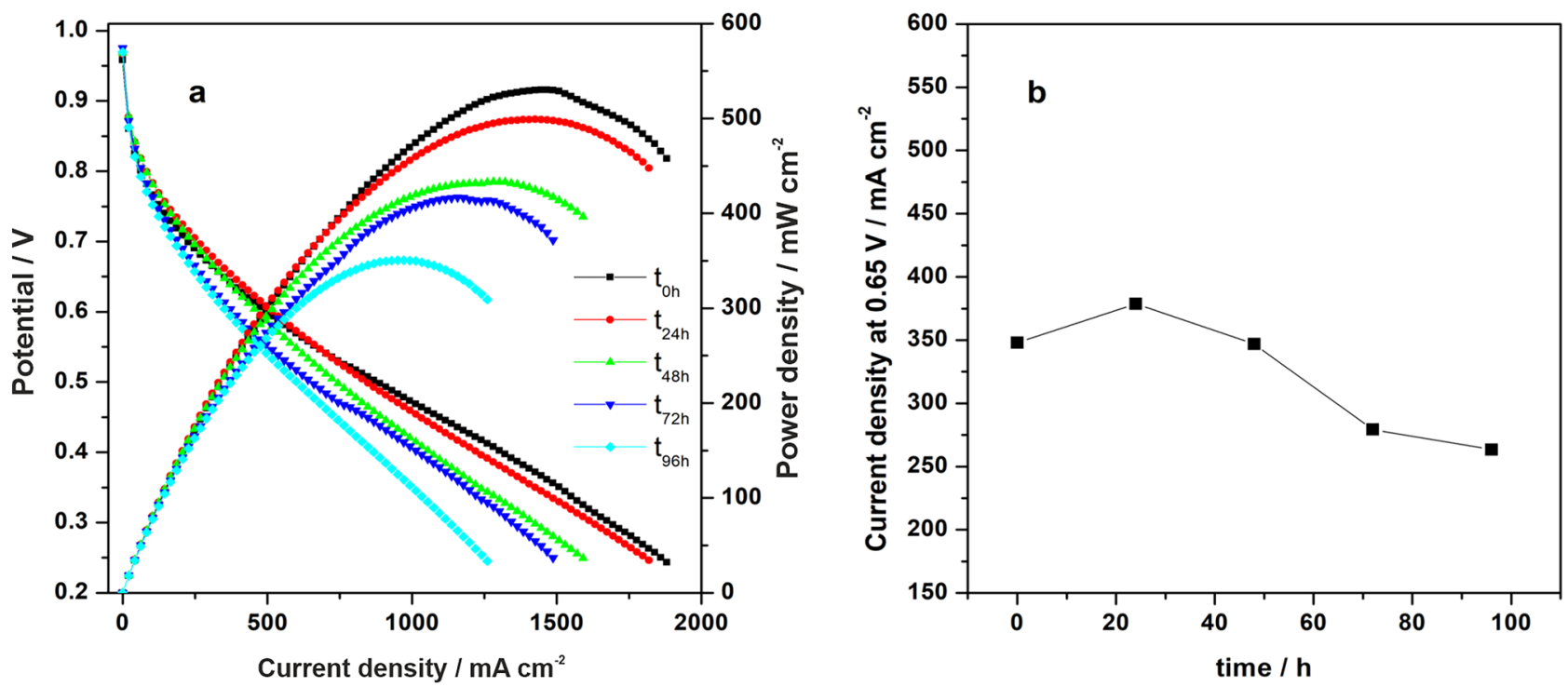

Fig. 7 a Accelerated stress test (AST) for the MEA with the POM3-3-9-modified PtFe/C at RH 100\%. b The changes of current density at $0.65 \mathrm{~V}$ during durability tests

polyoxometallates as co-support materials at the electrocatalytic interface. They are likely to interact with both $\mathrm{Pt}$ and $\mathrm{Fe}$ components, undergo chemisorption, form ultrathin films on their surfaces, and exhibit stabilizing effects during electrocatalytic applications [73]. The strategy reported in this work can be of practical importance when it comes to designing or upgrading electrocatalytic systems for fuel cell research and other catalytic applications.

\section{Conclusions}

The utility of $\mathrm{Cs}_{3} \mathrm{H}_{3} \mathrm{PMo}_{9} \mathrm{~V}_{3} \mathrm{O}_{40}$ polyoxometallate as cocatalyst, or co-support, for PtFe during electroreduction of oxygen acid medium has been demonstated here, and the resulting hybrid has been characterized by different physicochemical and electrochemical techniques. We have alo addressed the feasibility of applications in PEMFC. The MEA assembled with use of PtFe/POM modified cathode with low Pt loading has showed a comparable performance to the analogou commercial fuel cell at high $\mathrm{RH}$, despite the reduction of $\mathrm{Pt}$ mass content. Moreover, the improved performance of the modified cell has been found at low RH. It has been concluded that the enhanced activity is related to the high surface acidity of POM, thus increasing the proton availability and, consequently, improving the ORR kinetics. Furthermore, the high polyoxometalate mesoporosity can provide a humidity reservoir capable of maintaining the three-boundary contact between polymer electrolyte, electrode, and gaseous fuel. In addition, the presence of POM seems to improve the interfacial charge (electron, proton) transfer dynamics, which leads to promoting the ORR and compensating for the low Pt content at the cathode. The performed accelerated stress test (AST), utilizing the potential square wave between 0.4 and $0.8 \mathrm{~V}$, has been performed to evaluate MEA stability for ca. $100 \mathrm{~h}$. Following the initial insufficient performance for the first $48 \mathrm{~h}$, the system has exhibited promising stability until at least $96 \mathrm{~h}$. The initial decay can be explained in terms of the aging efects concerning first the particles outside the POM pores. The other particles, which are embedded inside the pores, have not been subject to degradation and, therefore, the current density has reached steady-state values after $48 \mathrm{~h}$ of testing. In other words, introduction of the polyoxometalate-cesium-salt cosupport/co-catalytic material results in hindering of the $\mathrm{Pt}$ particles aggregation and, consequently, in stable long-term operation.

Supplementary information The online version contains supplementary material available at https://doi.org/10.1007/s10008-021-05088-5.

Funding K.M. received support from National Science Centre (NCN, Poland) under project No. 2015/19/B/ST4/03758. P.J.K., I.A.R, and A. W. have been supported in part by National Science Centre (NCN, Poland) under Opus Project 2018/29/B/ST5/02627.

Open Access This article is licensed under a Creative Commons Attribution 4.0 International License, which permits use, sharing, adaptation, distribution and reproduction in any medium or format, as long as you give appropriate credit to the original author(s) and the source, provide a link to the Creative Commons licence, and indicate if changes were made. The images or other third party material in this article are included in the article's Creative Commons licence, unless indicated otherwise in a credit line to the material. If material is not included in the article's Creative Commons licence and your intended use is not 
permitted by statutory regulation or exceeds the permitted use, you will need to obtain permission directly from the copyright holder. To view a copy of this licence, visit http://creativecommons.org/licenses/by/4.0/.

\section{References}

1. Epping Martin K, Kopasz JP, McMurphy KW (2010) Status of fuel cells and the challenges facing fuel cell technology today making further progress in eliminating cost, durability, and performance challenges that remain for fuel cell technology. In: Fuel Cell Chemistry and Operation ACS Symposium Series. pp 1-13

2. Sørensen B, Spazzafumo G (2018) Fuel cells. In: Hydrogen and fuel cells (third edition) emerging technologies and applications. Academic Press, pp 107-220

3. Hoogers G (2002) Applications. In: Fuel cell technology handbook, First Edit. CRC Press, pp 8-1-11-30

4. Litster S, McLean G (2004) PEM fuel cell electrodes. J Power Sources 130:61-76. https://doi.org/10.1016/j.jpowsour.2003.12.055

5. Pollet BG, Kocha SS, Staffell I (2019) Current status of automotive fuel cells for sustainable transport. Curr Opin Electrochem 16:90-95. https://doi.org/10.1016/j.coelec.2019.04.021

6. Coralli A, Sarruf BJM, De Miranda PEV, Osmieri L, Specchia S, Minh NQ (2019) Fuel cells. In: Science and engineering of hydrogen-based energy technologies: hydrogen production and practical applications in energy generation. pp 39-122

7. Banham D, Ye S (2017) Current status and future development of catalyst materials and catalyst layers for proton exchange membrane fuel cells: an industrial perspective. ACS Energy Lett 2:629-638. https://doi.org/10.1021/acsenergylett.6b00644

8. He C, Desai S, Brown G, Bollepalli S (2005) PEM fuel cell catalysts: cost, performance, and durability. Electrochem Soc Interface 14:41-44. https://doi.org/10.1149/2.F07053IF

9. de Frank BA, Janssen GJM (2013) PEM fuel cell materials: costs, performance and durability. In: Kreuer K-D (ed) Fuel cells: selected entries from the encyclopedia of sustainability science and technology. Springer, New York, New York, NY, pp 249-303

10. Roen LM, Paik CH, Jarvi TD (2004) Electrocatalytic corrosion of carbon support in pemfc cathodes. Electrochem Solid-State Lett 7:A19-A22. https://doi.org/10.1149/1.1630412

11. Stevens DA, Hicks MT, Haugen GM, Dahn JR (2005) Ex situ and in situ stability studies of PEMFC catalysts. J Electrochem Soc 152:A2309-A2315. https://doi.org/10.1149/1.2097361

12. Cai M, Ruthkosky MS, Merzougui B, Swathirajan S, Balogh MP, Oh SH (2006) Investigation of thermal and electrochemical degradation of fuel cell catalysts. J Power Sources 160:977-986. https:// doi.org/10.1016/j.jpowsour.2006.03.033

13. Qiao Z, Wang C, Zeng Y, Spendelow JS, Wu G (2021) Advanced nanocarbons for enhanced performance and durability of platinum catalysts in proton exchange membrane fuel cells. Small 2006805. https://doi.org/10.1002/smll.202006805

14. Prokop M, Bystron T, Belsky P, Tucek O, Kodym R, Paidar M, Bouzek K (2020) Degradation kinetics of Pt during high-temperature PEM fuel cell operation Part III: voltage-dependent Pt degradation rate in single-cell experiments. Electrochim Acta 363:137165. https://doi.org/10.1016/j.electacta.2020.137165

15. Shahgaldi S, Hamelin J (2015) Improved carbon nanostructures as a novel catalyst support in the cathode side of PEMFC: a critical review. Carbon N Y 94:705-728. https://doi.org/10.1016/j.carbon.2015.07.055

16. Wang Q, Li B, Yang D, Dai H, Zheng JP, Ming P, Zhang C (2021) Research progress of heat transfer inside proton exchange membrane fuel cells. J Power Sources 492:229613. https://doi.org/10.1016/j.jpowsour.2021.229613
17. Yuan X-Z, Li H, Zhang S, Martin J, Wang H (2011) A review of polymer electrolyte membrane fuel cell durability test protocols. J Power Sources 196:9107-9116. https://doi.org/10.1016/j. jpowsour.2011.07.082

18. Yurko Y, Elbaz L (2021) The effect of membrane electrode assembly methods on the performance in fuel cells. Electrochim Acta 389:138676. https://doi.org/10.1016/j.electacta.2021.138676

19. Harzer GS, Orfanidi A, El-Sayed H, Madkikar P, Gasteiger HA (2018) Tailoring catalyst morphology towards high performance for low Pt loaded PEMFC cathodes. J Electrochem Soc 165:F770-F779. https://doi.org/10.1149/2.0311810jes

20. Dembinska B, Zlotorowicz A, Modzelewska M, Miecznikowski K, Rutkowska IA, Stobinski L, Malolepszy A, Krzywiecki M, Zak J, Negro E, Di Noto V, Kulesza PJ (2020) Low-noblemetal-loading hybrid catalytic system for oxygen reduction utilizing reduced-graphene-oxide-supported platinum aligned with carbon-nanotube-supported iridium. Catalysts 10:1-18. https://doi.org/10.3390/catal10060689

21. Martin S, Li Q, Jensen JO (2015) Lowering the platinum loading of high temperature polymer electrolyte membrane fuel cells with acid doped polybenzimidazole membranes. J Power Sources 293:51-56. https://doi.org/10.1016/j.jpowsour.2015.05.031

22. Pollet BG (2019) The use of power ultrasound for the production of PEMFC and PEMWE catalysts and low-pt loading and high-performing electrodes. Catalysts 9:246. https://doi.org/10. 3390/catal9030246

23. Song Z, Norouzi Banis M, Liu H, Zhang L, Zhao Y, Li J, DoyleDavis K, Li R, Knights S, Ye S, Botton GA, He P, Sun X (2019) Ultralow loading and high-performing Pt catalyst for a polymer electrolyte membrane fuel cell anode achieved by atomic layer deposition. ACS Catal 9:5365-5374. https://doi.org/10.1021/ acscatal.8b04504

24. Sui S, Wei Z, Su K, He A, Wang X, Su Y, Hou X, Raffet S, Du $S$ (2018) Pt nanowire growth induced by Pt nanoparticles in application of the cathodes for polymer electrolyte membrane fuel cells (PEMFCs). Int J Hydrogen Energy 43:20041-20049. https://doi.org/10.1016/j.ijhydene.2018.09.009

25. Wang J, Wu G, Xuan W, Peng L, Feng Y, Ding W, Li L, Liao Q, Wei Z (2021) A framework ensemble facilitates high Pt utilization in a low Pt loading fuel cell. Catal Sci Technol 11:2957-2963. https://doi.org/10.1039/D1CY00028D

26. Dsoke S, Moretti A, Giuli G, Marassi R (2011) Rotating disc electrode study of Pt-Co-Cs2.5PW $12 \mathrm{O} 40$ composite electrodes toward oxygen reduction reaction. Int J Hydrogen Energy 36:8098-8102. https://doi.org/10.1016/j.ijhydene.2011.01.101

27. Kostuch A, Rutkowska IA, Dembinska B, Wadas A, Negro E, Vezz K, Noto V Di, Kulesza PJ (2021) Enhancement of activity and development of low Pt content electrocatalysts for oxygen reduction reaction in acid media. Molecules 26:5147. https://doi. org/10.3390/molecules26175147

28. Zion N, Cullen DA, Zelenay P, Elbaz L (2020) Heat-treated aerogel as a catalyst for the oxygen reduction reaction. Angew Chemie Int Ed 59:2483-2489. https://doi.org/10.1002/anie.201913521

29. Zion N, Douglin JC, Cullen DA, Zelenay P, Dekel DR, Elbaz L (2021) Porphyrin aerogel catalysts for oxygen reduction reaction in anion-exchange membrane fuel cells. Adv Funct Mater 31:2100963. https://doi.org/10.1002/adfm.202100963

30. Kiani M, Tian XQ, Zhang W (2021) Non-precious metal electrocatalysts design for oxygen reduction reaction in polymer electrolyte membrane fuel cells: recent advances, challenges and future perspectives. Coord Chem Rev 441:213954. https://doi.org/10. 1016/j.ccr.2021.213954

31. Mazzucato M, Daniel G, Mehmood A, Kosmala T, Granozzi G, Kucernak A, Durante C (2021) Effects of the induced micro- and meso-porosity on the single site density and turn over frequency 
of Fe-N-C carbon electrodes for the oxygen reduction reaction. Appl Catal B Environ 291:120068. https://doi.org/10.1016/j. apcatb.2021.120068

32. Negro E, Bach Delpeuch A, Vezzù K, Nawn G, Bertasi F, Ansaldo A, Pellegrini V, Dembinska B, Zoladek S, Miecznikowski K, Rutkowska IA, Skunik-Nuckowska M, Kulesza PJ, Bonaccorso F, Di Noto V (2018) Toward Pt-free anion-exchange membrane fuel cells: Fe-Sn carbon nitride-graphene core-shell electrocatalysts for the oxygen reduction reaction. Chem Mater 30:2651-2659. https://doi.org/10. 1021/acs.chemmater.7b05323

33. Huang B, Yang D-H, Han B-H (2020) Application of polyoxometalate derivatives in rechargeable batteries. J Mater Chem A 8:4593-4628. https://doi.org/10.1039/C9TA12679A

34. Guedes G, Wang S, Santos HA, Sousa FL (2020) Polyoxometalate composites in cancer therapy and diagnostics. Eur J Inorg Chem 2020:2121-2132. https://doi.org/10.1002/ejic.202000066

35. Wang D, Liu L, Jiang J, Chen L, Zhao J (2020) Polyoxometalatebased composite materials in electrochemistry: state-of-the-art progress and future outlook. Nanoscale 12:5705-5718. https:// doi.org/10.1039/C9NR10573E

36. Lai SY, Ng KH, Cheng CK, Nur H, Nurhadi M, Arumugam M (2021) Photocatalytic remediation of organic waste over Keggin-based polyoxometalate materials: a review. Chemosphere 263:128244. https:// doi.org/10.1016/j.chemosphere.2020.128244

37. Chojak M, Kolary-Zurowska A, Wlodarczyk R, Miecznikowski K, Karnicka K, Palys B, Marassi R, Kulesza PJ (2007) Modification of Pt nanoparticles with polyoxometallate monolayers: competition between activation and blocking of reactive sites for the electrocatalytic oxygen reduction. Electrochim Acta 52:5574-5581. https://doi.org/10.1016/j.electacta.2007.01.063

38. Karnicka K, Chojak M, Miecznikowski K, Skunik M, Baranowska B, Kolary A, Piranska A, Palys B, Adamczyk L, Kulesza PJ (2005) Polyoxometallates as inorganic templates for electrocatalytic network films of ultra-thin conducting polymers and platinum nanoparticles. Bioelectrochemistry 66:79-87. https://doi.org/10.1016/j. bioelechem.2004.06.005

39. Kulesza PJ, Karnicka K, Miecznikowski K, Chojak M, Kolary A, Barczuk PJ, Tsirlina G, Czerwinski W (2005) Network electrocatalytic films of conducting polymer-linked polyoxometallatestabilized platinum nanoparticles. Electrochim Acta 50:51555162. https://doi.org/10.1016/j.electacta.2005.03.061

40. Kulesza PJ, Skunik M, Baranowska B, Miecznikowski K, Chojak M, Karnicka K, Frackowiak E, Béguin F, Kuhn A, Delville M-H, Starobrzynska B, Ernst A (2006) Fabrication of network films of conducting polymer-linked polyoxometallate-stabilized carbon nanostructures. Electrochim Acta 51:2373-2379. https://doi.org/ 10.1016/j.electacta.2005.06.041

41. Kourasi M, Wills RGA, Shah AA, Walsh FC (2014) Heteropolyacids for fuel cell applications. Electrochim Acta 127:454-466. https://doi.org/10.1016/j.electacta.2014.02.006

42. Okuhara T (2002) Water-tolerant solid acid catalysts. Chem Rev 102:3641-3666. https://doi.org/10.1021/cr0103569

43. Adamczyk L, Cox JA, Miecznikowski K (2017) Activation of a Ptbased alloy by a Keggin-type cesium salt of heteropolytungstate towards electrochemical oxidation of ethylene glycol in acidic medium. Int J Hydrogen Energy 42:5035-5046. https://doi.org/ 10.1016/j.ijhydene.2016.11.011

44. Wlodarczyk R, Chojak M, Miecznikowski K, Kolary A, Kulesza PJ, Marassi R (2006) Electroreduction of oxygen at polyoxometallatemodified glassy carbon-supported Pt nanoparticles. J Power Sources 159:802-809. https://doi.org/10.1016/j.jpowsour.2005.11.061

45. Wlodarczyk R, Kolary-Zurowska A, Marassi R, Chojak M, Kulesza PJ (2007) Enhancement of oxygen reduction by incorporation of heteropolytungstate into the electrocatalytic ink of carbon supported platinum nanoparticles. Electrochim Acta 52:3958-3964. https://doi.org/10.1016/j.electacta.2006.11.011
46. Medetalibeyoğlu H, Manap S, Yokuş ÖA, Beytur M, Kardaş F, Akyıldırım O, Özkan V, Yüksek H, Yola ML, Atar N (2018) Fabrication of $\mathrm{Pt} / \mathrm{Pd}$ nanoparticles/polyoxometalate/ionic liquid nanohybrid for electrocatalytic oxidation of methanol. J Electrochem Soc 165:F338-F341. https://doi.org/10.1149/2.1041805jes

47. Ingavale S, Patil I, Prabakaran K, Swami A (2021) Microwave-assisted synthesis of cobalt-polyoxometalate@carbon black nanocomposites and their electrocatalytic ability toward oxygen reduction reaction. Int J Energy Res 45:7366-7379. https://doi.org/10.1002/er.6321

48. Dsoke S, Kolary-Zurowska A, Zurowski A, Mignini P, Kulesza PJ, Marassi R (2011) Rotating disk electrode study of Cs2.5H0.5PW12O40 as mesoporous support for Pt nanoparticles for PEM fuel cells electrodes. J Power Sources 196:10591-10600. https://doi.org/10.1016/j.jpowsour.2011.09.010

49. Kolary-Zurowska A, Zurowski A, Dsoke S, Dembinska B, Zoladek S, Kiliszek M, Marassi R, Kulesza PJ (2014) Electrocatalytic properties of platinum nanocenters electrogenerated at ultra-trace levels within zeolitic phosphododecatungstate cesium salt matrices. J Solid State Electrochem 18:2993-3001. https:// doi.org/10.1007/s10008-014-2537-5

50. Renzi M, Agostini M, Navarra MA, Nobili F (2017) An innovative membrane-electrode assembly for efficient and durable polymer electrolyte membrane fuel cell operations. Int J Hydrogen Energy 42:16686-16694. https://doi.org/10.1016/j.ijhydene.2017.05.168

51. Koyano G, Ueno K, Misono M (1999) Three types of acid catalysis in liquid phase of metal salts of 12-tungstophosphoric acid, $\mathrm{Mn}+\mathrm{xH} 3-\mathrm{nxPW} 12 \mathrm{O} 401 \mathrm{Catalysis}$ by heteropoly compounds. Part 41.1. Appl Catal A Gen 181:267-275. https://doi.org/10.1016/ S0926-860X(98)00398-6

52. Gasteiger HA, Kocha SS, Sompalli B, Wagner FT (2005) Activity benchmarks and requirements for Pt, Pt-alloy, and non-Pt oxygen reduction catalysts for PEMFCs. Appl Catal B Environ 56:9-35. https://doi.org/10.1016/j.apcatb.2004.06.021

53. Xu W, Lu T, Liu C, Xing W (2005) Low methanol permeable composite Nafion/silica/PWA membranes for low temperature direct methanol fuel cells. Electrochim Acta 50:3280-3285. https://doi.org/10.1016/j.electacta.2004.12.014

54. Tang Y, Karlsson AM, Santare MH, Gilbert M, Cleghorn S, Johnson WB (2006) An experimental investigation of humidity and temperature effects on the mechanical properties of perfluorosulfonic acid membrane. Mater Sci Eng A 425:297-304. https://doi.org/10.1016/j. msea.2006.03.055

55. Langpape M, Millet JMM, Ozkan US, Delichère $P$ (1999) Study of cesium or cesium-transition metal-substituted Keggin-type phosphomolybdic acid as isobutane oxidation catalysts: I. Structural Characterization J Catal 181:80-90. https://doi.org/10.1006/ jcat.1998.2359

56. Sun M, Zhang J, Cao C, Zhang Q, Wang Y, Wan H (2008) Significant effect of acidity on catalytic behaviors of Cs-substituted polyoxometalates for oxidative dehydrogenation of propane. Appl Catal A Gen 349:212-221. https://doi.org/10.1016/j.apcata.2008.07.035

57. Duch J, Mazur M, Golda-Cepa M, Podobiński J, Piskorz W, Kotarba A (2018) Insight into modification of electrodonor properties of multiwalled carbon nanotubes via oxygen plasma: Surface functionalization versus amorphization. Carbon N Y 137:425-432. https://doi.org/10.1016/j.carbon.2018.05.059

58. Xue Q, Yang D, Jiang L, Li B, Ming P (2021) Modifying carbon supports of catalyst for the oxygen reduction reaction in vehicle PEMFCs. Automot Innov 4:119-130. https://doi.org/10.1007/ s42154-021-00149-x

59. Renzi M, Mignini P, Giuli G, Marassi R, Nobili F (2016) Rotating disk electrode study of Pt/Cs3HPMo11VO40 composite catalysts for performing and durable PEM fuel cells. Int J Hydrogen Energy 41:11163-11173. https://doi.org/10.1016/j.ijhydene.2016.04.194

60. Paulus UA, Schmidt TJ, Gasteiger HA, Behm RJ (2001) Oxygen reduction on a high-surface area Pt/Vulcan carbon catalyst: a 
thin-film rotating ring-disk electrode study. J Electroanal Chem 495:134-145. https://doi.org/10.1016/S0022-0728(00)00407-1

61. Di Noto V, Negro E, Nale A, Kulesza PJ, Rutkowska IA, Vezzù K, Pagot G (2020) Correlation between precursor properties and performance in the oxygen reduction reaction of $\mathrm{Pt}$ and Co "core-shell" carbon nitride-based electrocatalysts. Electrocatalysis 11:143-159. https://doi.org/10.1007/s12678-019-00569-8

62. Masa J, Batchelor-McAuley C, Schuhmann W, Compton RG (2014) Koutecky-Levich analysis applied to nanoparticle modified rotating disk electrodes: electrocatalysis or misinterpretation. Nano Res 7:71-78. https://doi.org/10.1007/s12274-013-0372-0

63. Ge X, Sumboja A, Wuu D, An T, Li B, Goh FWT, Hor TSA, Zong Y, Liu Z (2015) Oxygen reduction in alkaline media: from mechanisms to recent advances of catalysts. ACS Catal 5:4643-4667. https://doi.org/10.1021/acscatal.5b00524

64. Du C, Tan Q, Yin G, Zhang J (2014) Rotating disk electrode method. In: Rotating electrode methods and oxygen reduction electrocatalysts. Elsevier BV 171-198

65. Di Noto V, Pagot G, Negro E, Vezzù K, Kulesza PJ, Rutkowska IA, Pace G (2022) A formalism to compare electrocatalysts for the oxygen reduction reaction by cyclic voltammetry with the thin-film rotating ring-disk electrode measurements. Curr Opin Electrochem 31:100839. https://doi.org/10.1016/j.coelec.2021.100839

66. Holewinski A, Linic S (2012) Elementary mechanisms in electrocatalysis: revisiting the ORR Tafel slope. J Electrochem Soc 159:H864-H870. https://doi.org/10.1149/2.022211jes

67. Wang JX, Markovic NM, Adzic RR (2004) Kinetic analysis of oxygen reduction on $\mathrm{Pt}(111)$ in acid solutions: intrinsic kinetic parameters and anion adsorption effects. J Phys Chem B 108:4127-4133. https://doi. org/10.1021/jp037593v
68. Renzi M, D’Angelo G, Marassi R, Nobili F (2016) Low platinum loading cathode modified with Cs3H2PMo10V2O40 for polymer electrolyte membrane fuel cells. J Power Sources 327:11-20. https://doi.org/10.1016/j.jpowsour.2016.07.024

69. Zhang J, Tang Y, Song C, Cheng X, Zhang J, Wang H (2007) PEM fuel cells operated at $0 \%$ relative humidity in the temperature range of $23-120^{\circ} \mathrm{C}$. Electrochim Acta 52:5095-5101. https://doi. org/10.1016/j.electacta.2007.02.002

70. Du XX, He Y, Wang XX, Wang JN (2016) Fine-grained and fully ordered intermetallic PtFe catalysts with largely enhanced catalytic activity and durability. Energy Environ Sci 9:2623-2632. https://doi.org/10.1039/c6ee01204c

71. Petkov V, Prasai B, Shastri S, Park HU, Kwon YU, Skumryev V (2017) Ensemble averaged structure-function relationship for nanocrystals: effective superparamagnetic Fe clusters with catalytically active Pt skin. Nanoscale 9:15505-15514. https://doi.org/10. 1039/c7nr05768g

72. Jang JH, Lee E, Park J, Kim G, Hong S, Kwon YU (2013) Rational syntheses of core-shell Fe x @Pt nanoparticles for the study of electrocatalytic oxygen reduction reaction. Sci Rep 3:1-8. https:// doi.org/10.1038/srep02872

73. Kulesza PJ, Chojak M, Karnicka K, Miecznikowski K, Palys B, Lewera A, Wieckowski A (2004) Network films composed of conducting polymer-linked and polyoxometalate-stabilized platinum nanoparticles. Chem Mater 16:4128-4134. https://doi.org/10. $1021 / \mathrm{cm} 040010 \mathrm{p}$

Publisher's Note Springer Nature remains neutral with regard to jurisdictional claims in published maps and institutional affiliations. 